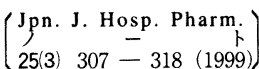

高カロリー輸液キット製剤の外包装開封後および隔壁開通後の溶液の安定性

\author{
山岡桂子, 中島康雄 \\ 帝京大学医学部附属病院薬郕部†
}

\title{
Stability of Various Compositions in the Solution after being Excluded the Plastic Exterior Bag for TPN Kit and after being Broken Kit's Partition
}

\author{
KEIKO YAMAOKA and YASUO NAKAJIMA \\ Department of Pharmacy, Teikyo University Hospital $\dagger$ \\ $\left(\begin{array}{ll}\text { Received October 9, } & 1998 \\ \text { Accepted February } 12, & 1999\end{array}\right)$
}

We evaluated the stability of various compositions after the plastic exterior bag of the TPN kit leaked out and the kit's partition broke.

PN-twin-2 and Aminotripa 2 leaked out of the plastic exterior bag in the double chambered type TPN kit, after being stored at room temperature for 14 days, a slight degree of coloration was noticed on the amino acid layer, while the $A_{350}$ level (index for tryptophan degradation) was increasing.

Coloration was evident after the kit's partition broke, and the residual rate of glucose and amino acids were over $95 \%$.

As for Unicaliq $\mathrm{N}$, the residual glucose and amino acid rates were also over $95 \%$.

Key words — stability, double-chambered type TPN kit, one bag type TPN kit, amino acid, glucose

\section{緒言}

高カロリ一輸液療法（TPN）は, 腸管からの栄 養搷取が不可能あるいは困難な患者に対し不可欠 な栄養療法として, 幅広く普及している.ここ数 年来, 糖・電解質液とアミノ酸液を用時開通する 隔壁で仕切ったダブルバッグ型 TPN 製㓮や，還 元糖とアミノ酸の配合によるメイラード反応を製 剤技術により軽減して糖・電解質液とアミノ酸液 を一液中に混合したワンバッグ型 TPN 製剤が相

$\dagger$ 東京都板橋区加賀2-11-1；2-11-1, Kaga, Itabashiku, Tokyo, 173-0016 Japan
次いで市販されている。これら製剈の使用により 無菌性の優れた TPNの調製が簡便に行えるよう になってきている1).

これらの TPNキット製剤はいずれもプラス チック製のソフトバッグを使用しており，製品の 安定性を保持するために脱酸素剤を封入して酸素 透過性の低いフィルムでバッグを包んでいる。そ のため, 外包装は使用直前まで開封しないことと されているが, 臨床現場では点滴の準備作業とし てあらかじめ外包装を開封して保存しておいた り，開封後に使用中止となることがしばしばあ る.また，ダブルバッグ型製剤の隔壁を開通して 
おきながら，使用中止となる場合も想定される．

筆者らは以前, ダブルバッグ型 TPN 製剈の ピーエヌッイン®について外包装開封後および隔 壁開通後の安定性試験を行い, 室温保存 1 週間, 冷所保存 4 週間程度は品質に影響はないとの結論 を出した2).ピーエヌッイン®のアミノ酸液層中 に添加されている亜硫酸水素ナトリウムは酸化防 止の役割を持っているが，一方ではビタミン $\mathrm{B}_{1}$ を容易に分解することが知られている ${ }^{3,4)}$.その 影響を少なくするために亜硫酸水素ナトリウム量 を従来の $1 / 3$ に減量した改良型が製品化された

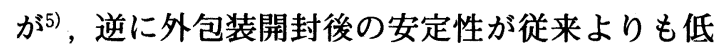
下するのではないかと䊝念される，そこで今回 は, 改良型ピーエヌッイン®おび他の TPN キッ ト製肪について前回と同様の安定性試験を行い, 比較検討したので報告する。

\section{方法}

ダブルバッグ型 TPN 製剤としてピーエヌッイ ン ${ }^{\circledR} 2$ 号（混合後 $1100 \mathrm{~mL}$, Lot.No. $7 \mathrm{~J} 09 \mathrm{~A}$ ，日本 ヘキスト・マリオンルセル, 以下 $\mathrm{PN}-2$ と略) およびアミノトリパ®2号（混合後 $900 \mathrm{~mL}$, Lot. No.M 6 A73，大塚製薬，以下AT-2 と略）を， ワンバッグ型 TPN 製刻としてユニカリック ${ }^{\circledR} \mathrm{N}$ (容量1000mL, Lot.No.970701NA, テルモ, 以下 UC-N と略）を用いて試験を行った。表 1 に各製 鼡の組成を示した。
測定項目，測定条件は表 2 に示した．機器は下 記のものを用いた。

pH メーター (DELTA METTER) 分光光度計 (島 津製作所 SIPPER160）アミノ酸分析計（日本電 子 JLC-500V)

\section{結果}

\section{1. 外包装開封後の安定性試験}

PN-2の外包装開封後の安定性試験結果を表 3，4 に示した. 室温保存での外観は糖・電解質 液層（Ｉ層），アミノ酸液層（II層）ともに外包 装開封 7 日後まで無色清澄であったが，II層は14 日後で微黄色清澄となった. $\mathrm{T}_{430} \%$ は I 層，II層 ともに 14 日後まで $98 \%$ 以上り，経時的な変動は 認められなかった. $\mathrm{pH}$ は I 層が約4.6，II層が約 6.0で, ともに変動は認められず，I層の $\mathrm{A}_{284}$ も 約0.1で変動は認められなかった．II層の $\mathrm{A}_{350}$ は 開封直後が 0.14 であったのが，14日後では0.237 とわずかに上昇していた．冷暗所保存での外観 は，I層，II層ともに28日後まで無色清澄で着色 は認められず， $\mathrm{T}_{430} \%, \mathrm{pH}$ とも28日後まで経時的 な変動は認められなかった. I 層の $\mathrm{A}_{284}$ も28日後 まで変動は認められなかったが，II層の $\mathrm{A}_{350}$ は若 干の上昇傾向がみられた。

AT-2の外包装開封後の安定性試験結果を表 5，6に示した。室温保存での外観は, 糖・電解 質液層 (下室), アミノ酸液層（上室）ともに外

表 1。高カロリー輸液キット製郕の組成

\begin{tabular}{|c|c|c|c|c|c|c|}
\hline 品 & バッグの形式 & 容量 $(\mathrm{mL})$ & 糖 $(\mathrm{g})$ & $\begin{array}{l}\text { アミノ酸 } \\
(\mathrm{g})\end{array}$ & 添加物（mg） & バッグの材質 \\
\hline ピーエヌツイン®-2号 & ダブルバッグ & 1100 & ブドウ糖180 & 30.0 & 亜硫酸水素 Na45 & $\begin{array}{l}\text { 外層ポリエチレン } \\
\text { 内層ポリエチレン } \\
\text { ＋゚リプロピレン }\end{array}$ \\
\hline アミノトリパ囚-2号 & ダブルバッグ & 900 & $\begin{array}{lr}\text { ブドウ糖 } & 100.2 \\
\text { 果糖 } & 49.8 \\
\text { キシリトール25.2 }\end{array}$ & 30.0 & 亜硫酸水素 Na360 & $\begin{array}{l}\text { ポリエチレン } \\
\text { 隔壁部を高密度化 }\end{array}$ \\
\hline ユニカリック®N & ワンバッグ & 1000 & ブドウ糖175 & 29.98 & $\begin{array}{l}\text { 亜硫酸水素 Na480 } \\
\text { L-塩酸システイン150 }\end{array}$ & $\begin{array}{l}\text { エチレン酢酸ビニル } \\
\text { 共重合体 }\end{array}$ \\
\hline
\end{tabular}


表 2. 試験方法・試験条件

\begin{tabular}{|c|c|c|c|c|c|c|}
\hline \multirow[b]{3}{*}{ 保存条件 } & \multicolumn{4}{|c|}{ PN-2 、 AT-2 } & \multirow{2}{*}{\multicolumn{2}{|c|}{$\frac{U C-N}{\text { 外包装明封後 }}$}} \\
\hline & \multicolumn{2}{|c|}{ 外包䒧閶封後 } & \multicolumn{2}{|c|}{ 同照開通後 } & & \\
\hline & $\begin{array}{l}\text { (22 26 } \\
{ }^{\circ} \text { C) } \\
\text { 蛍光奵500lux } \\
\text { 1日10时间照射 }\end{array}$ & 冷暗所5ๆ & 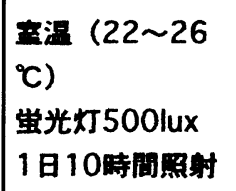 & 冷暗所5 & 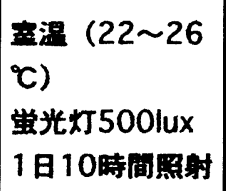 & 冷疃所50 \\
\hline 测定時点 & $\begin{array}{l}\text { 䦎封直後、1， } \\
\text { 3、7、14日後 }\end{array}$ & $\begin{array}{l}\text { 開封直後、 } \\
3.7 、 14 \text { 、 } \\
28 \text { 日後 }\end{array}$ & 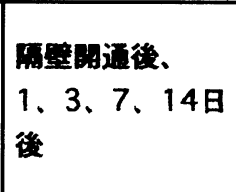 & 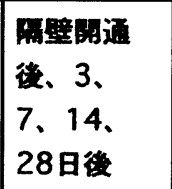 & $\begin{array}{l}\text { 闍封杏後、1、 } \\
\text { 3，7，14日後 }\end{array}$ & $\begin{array}{l}\text { 明封直後、 } \\
3 、 7 、 14 \text {. } \\
28 \text { 日後 }\end{array}$ \\
\hline 試资項目 & 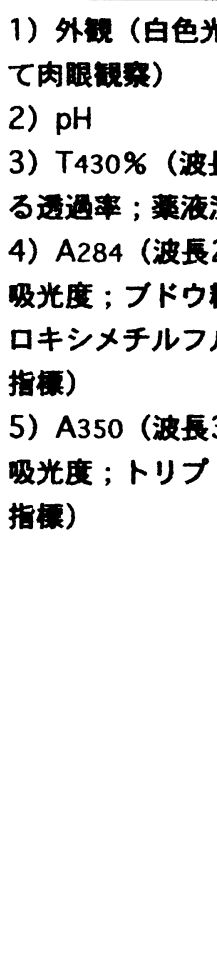 & 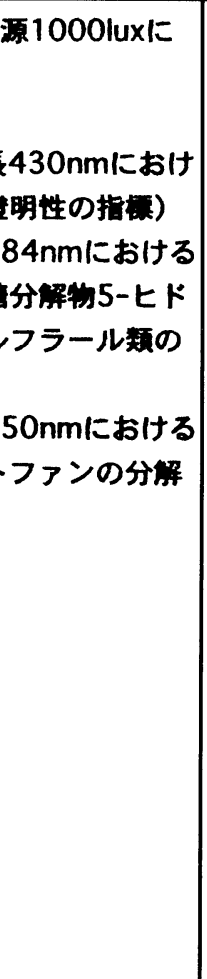 & 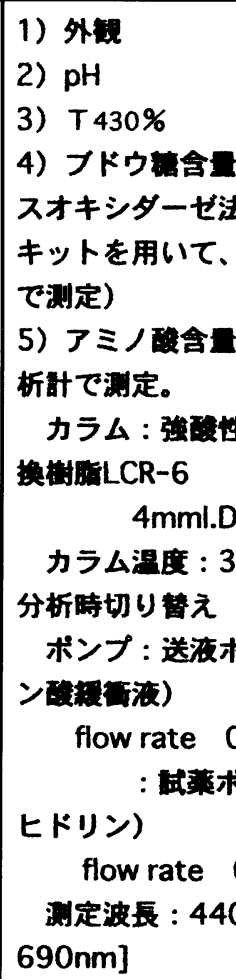 & 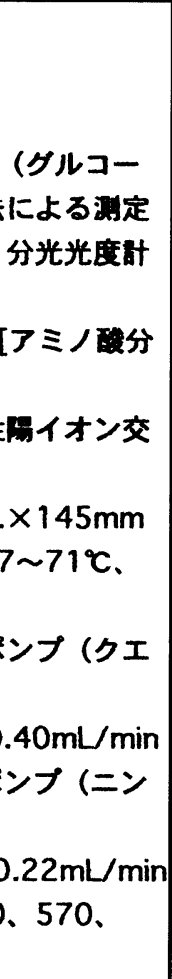 & 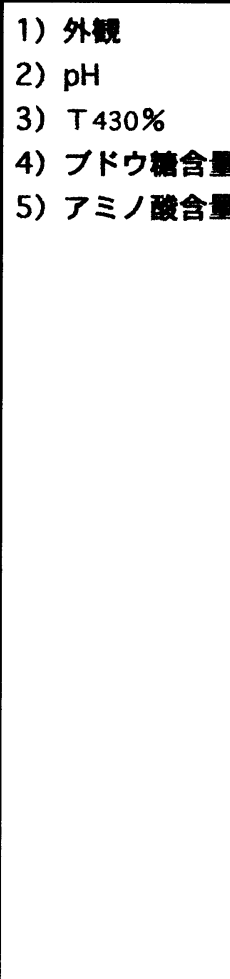 & \\
\hline
\end{tabular}


表 3 ．外包装開封後の安定性一室温保存（蛍光灯500lux 1日約10時間照射）

ピーエヌツイン®ー2号

\begin{tabular}{|c|c|c|c|c|c|c|}
\hline & & & & & & $n=3$ \\
\hline & & 開封直後 & 1日後 & 3日後 & 7日後 & 14日後 \\
\hline & 外観 & 無色清澄 & 無色清澄 & 無色清澄 & 無色清澄 & 無色清澄 \\
\hline I & T $430 \%$ & 99.5 & 98.8 & 99.5 & 99.6 & 99.8 \\
\hline 層 & $\mathrm{pH}$ & 4.55 & 4.55 & 4.55 & 4.56 & 4.60 \\
\hline & A 284 & 0.099 & 0.095 & 0.101 & 0.095 & 0.097 \\
\hline & 外観 & 無色清澄 & 無色清澄 & 無色清澄 & 無色清澄 & 微黄色清澄 \\
\hline II & T $430 \%$ & 98.3 & 98.8 & 98.7 & 99.0 & 98.7 \\
\hline 層 & $\mathrm{pH}$ & 5.99 & 5.98 & 5.96 & 6.00 & 6.00 \\
\hline & A 350 & 0.140 & 0.130 & 0.161 & 0.196 & 0.237 \\
\hline
\end{tabular}

表 4. 外包装開封後の安定性一冷暗所保存 ピーエヌッイン® ${ }^{\circledR}-2$ 号

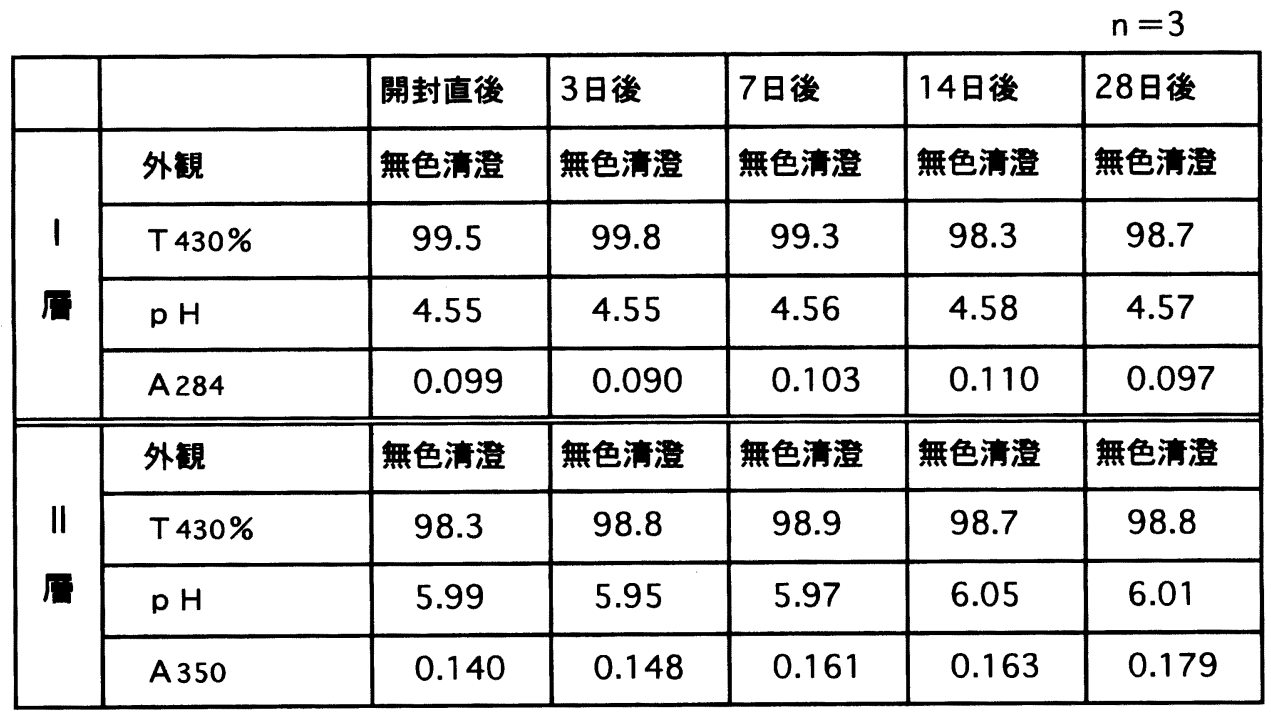

包装開封 7 日後まで無色清澄であったが，上室は 14日後に微黄色清澄となった. $\mathrm{T}_{430} \%$ とH $\mathrm{pH}$ 室, 下室ともに経時的な変動は認められず, 下室 の $\mathrm{A}_{284}$ も変動は認められなかったが, 上室の $\mathrm{A}_{350}$ は開封直後の0.037から14日後では0.24にまで上
昇していた．冷暗所保存では，下室については何 ら経時的な変動は認められなかったものの, 上室 は外包装開封28日後で微黄色澄明となり， $\mathrm{A}_{3,50}$ が 0.159にまで上昇していた。 
表 5. 外包装開封後の安定性一室温保存（蛍光灯500lux 1日約10時間照射）

アミノトリパ®2号

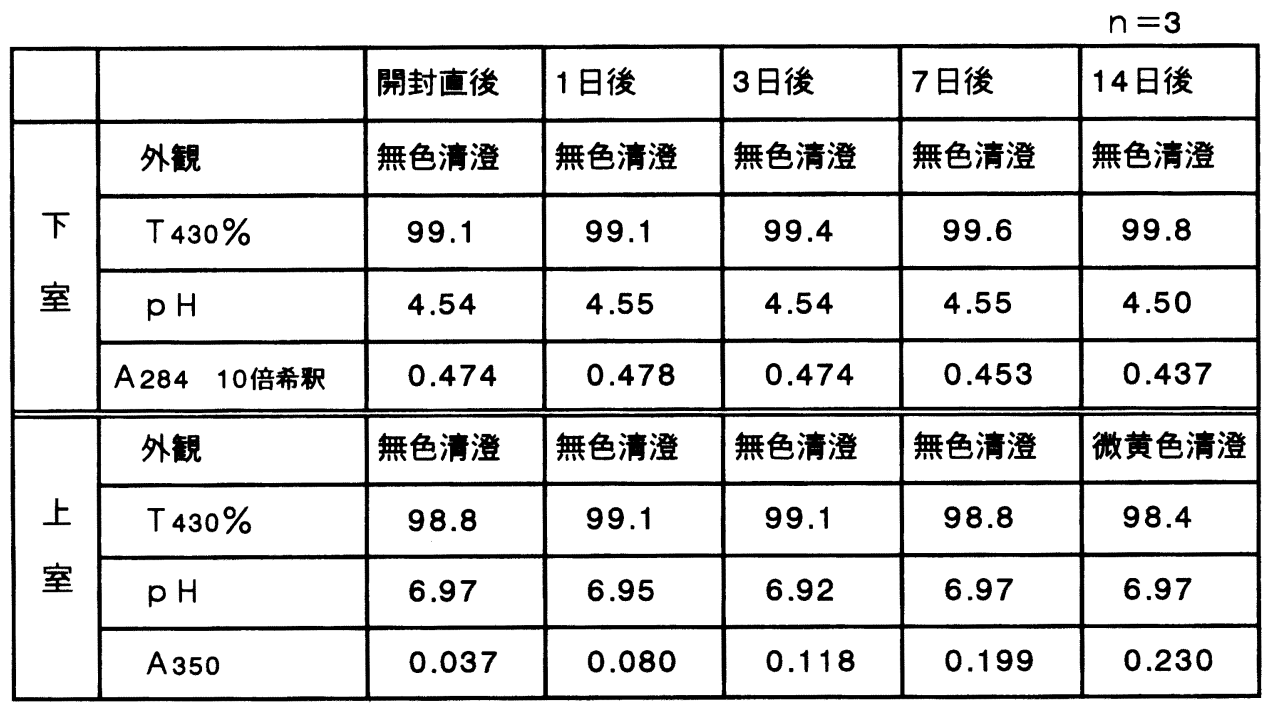

表 6 . 外包装開封後の安定性一冷暗所保存 アミノトリパ囚 2 号

\begin{tabular}{|c|c|c|c|c|c|c|}
\hline & & & & & & $n=8$ \\
\hline & & 開封直後 & 3日後 & 7日後 & 14日後 & 28日後 \\
\hline & 外観 & 無色清澄 & 無色清澄 & 無色清澄 & 無色清澄 & 無色清澄 \\
\hline 下 & $\mathrm{T} 430 \%$ & 99.1 & 99.6 & 99.7 & 99.3 & 99.6 \\
\hline 室 & $\mathrm{pH}$ & 4.54 & 4.55 & 4.54 & 4.58 & 4.59 \\
\hline & A 284 10倍希粎 & 0.474 & 0.473 & 0.476 & 0.477 & 0.481 \\
\hline & 外篗 & 無色清澄 & 無色清澄 & 無色清澄 & 無色清澄 & 微黄色清澄 \\
\hline 上 & T $430 \%$ & 98.8 & 98.8 & 99.2 & 99.1 & 98.1 \\
\hline 室 & $\mathrm{pH}$ & 6.97 & 6.92 & 6.94 & 7.01 & 6.99 \\
\hline & A 350 & 0.037 & 0.073 & 0.084 & 0.125 & 0.159 \\
\hline
\end{tabular}

2. 隔壁開通混合後の安定性

PN-2の隔壁開通混合後の安定性試験結果を表 7，8に示した。外観は室温保存 7 日後までは無 色清澄であったのが, 室温保存14日後では微黄色 清澄となった。しかし， $\mathrm{T}_{430} \%$ は $99 \%$ 以上りり変
動は認められなかった。 $\mathrm{pH}$ は5.1で変動は認めら れず，ブドウ糖残存率も室温保存14日後で $98 \%$ 以 上, 各アミノ酸の残存率もすべて $95 \%$ 以上であっ た.PN-2の冷暗所保存での外観は28日後まで無 色清澄であり, 着色は認められなかった。 $\mathrm{T}_{430} \%$, 
表 7 . 隔壁開通後の安定性一室温保存（蛍光灯500lux 1日約10時間照射） ピーエヌッイン®-2号

\begin{tabular}{|c|c|c|c|c|c|}
\hline & 開封直後 & 1日後 & 3日後 & 7日後 & 14 日後 \\
\hline 外観 & 無色清澄 & 無色清澄 & 無色清澄 & 無色清澄 & 微黄色清澄 \\
\hline$T_{430 \%}$ & 99.3 & 99.1 & 99.5 & 99.3 & 99.1 \\
\hline $\mathrm{pH}$ & 5.10 & 5.08 & 5.06 & 5.08 & 5.08 \\
\hline ブドウ糖残存率 $(\%)$ & 100 & 101.6 & 97.3 & 97.9 & 98.1 \\
\hline \multicolumn{6}{|l|}{ アミノ酸残存率 (\%) } \\
\hline アスパラギン酸 & 100 & 100.2 & 98.3 & 99.9 & 99.5 \\
\hline トレオニン & 100 & 99.9 & 98.0 & 99.2 & 98.4 \\
\hline セリン & 100 & 101.1 & 98.9 & 100.6 & 99.3 \\
\hline グルタミン酸 & 100 & 99.8 & 98.0 & 99.6 & 98.7 \\
\hline プロリン & 100 & 98.6 & 99.0 & 100.5 & 98.5 \\
\hline グリシン & 100 & 99.6 & 98.8 & 100.1 & 98.9 \\
\hline アラニン & 100 & 99.8 & 98.2 & 99.7 & 98.8 \\
\hline バリン & 100 & 99.8 & 97.9 & 99.3 & 98.2 \\
\hline メチオニン & 100 & 99.9 & 98.4 & 99.0 & 97.9 \\
\hline イソロイシン & 100 & 99.8 & 97.9 & 99.0 & 97.1 \\
\hline ロイシン & 100 & 99.9 & 97.8 & 99.2 & 99.0 \\
\hline チロシン & 100 & 98.9 & 99.5 & 98.7 & 98.9 \\
\hline フェニルアラニン & 100 & 99.9 & 97.5 & 99.5 & 98.0 \\
\hline ヒスチジン & 100 & 98.9 & 99.5 & 100.2 & 98.1 \\
\hline リジン & 100 & 99.8 & 100.8 & 101.5 & 99.3 \\
\hline トリプトファン & 100 & 98.5 & 99.3 & 96.8 & 95.8 \\
\hline アルギニン & 100 & 99.2 & 100.2 & 100.5 & 100.1 \\
\hline
\end{tabular}

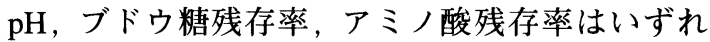
も変動は認められなかった。

AT-2の隔壁開通混合後の安定性試験結果を表 9，10に示した. 外観は無色清澄であったのが， 室温保存 7 日後では微黄色清澄となったが, $\mathrm{T}_{430} \%$
は14日後でも $98 \%$ 以あり変動は認められなかっ た. $\mathrm{pH}$ は 5.5 と変動は認められなかった. ブドゥ 糖残存率は室温保存14日後でも $98 \%$, アミノ酸残 存率もすべて $99 \%$ 以上であった，AT-2 の冷暗所 保存での外観は28日後まで無色清澄であり, 着色 
表 8. 隔壁開通後の安定性一冷暗所保存ピーエヌッイン® ${ }^{\circledR} 2$ 号

\begin{tabular}{|c|c|c|c|c|c|}
\hline & & & & & $n=3$ \\
\hline & 開封直後 & 3日後 & 7日後 & 14 日後 & 28日後 \\
\hline 外薙 & 無色清澄 & 無色清澄 & 無色清澄 & 無色清澄 & 微黄色清澄 \\
\hline$T_{430 \%}$ & 99.3 & 99.3 & 99.7 & 99.6 & 99.5 \\
\hline & 5.10 & 5.07 & 5.08 & 5.11 & 5.11 \\
\hline 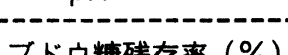 & & & ---1 & & \\
\hline ブドウ糖残存率（％） & 100 & 102.9 & 98.8 & 98.9 & 97.9 \\
\hline アミノ酸残存种 (\%) & & & & & \\
\hline アスパラギン酸 & 100 & 99.3 & 99.1 & 99.2 & 99.3 \\
\hline トレオニン & 100 & 99.4 & 99.2 & 98.3 & 98.7 \\
\hline セリン & 100 & 100.4 & 100.4 & 100.0 & 101.0 \\
\hline グルタミン酸 & 100 & 98.9 & 98.9 & 98.7 & 99.4 \\
\hline プロリン & 100 & 99.2 & 99.5 & 97.6 & 98.3 \\
\hline グリシン & 100 & 99.9 & 99.8 & 100.1 & 99.7 \\
\hline アラニン & 100 & 99.6 & 99.8 & 99.4 & 99.0 \\
\hline パリン & 100 & 99.5 & 99.7 & 98.3 & 99.5 \\
\hline メチオニン & 100 & 100.2 & 99.8 & 97.7 & 98.6 \\
\hline イソロイシン & 100 & 100.2 & 99.7 & 98.4 & 98.6 \\
\hline ロイシン & 100 & 99.5 & 100.0 & 98.4 & 99.2 \\
\hline チロシン & 100 & 98.4 & 97.6 & 97.9 & 96.4 \\
\hline フェニルアラニン & 100 & 98.9 & 99.2 & 97.9 & 98.9 \\
\hline ヒスチジン & 100 & 100.5 & 101.6 & 100.2 & 100.3 \\
\hline リジン & 100 & 102.3 & 103.8 & 101.1 & 101.7 \\
\hline トリプトファン & 100 & 99.5 & 100.0 & 96.7 & 97.2 \\
\hline アルギニン & 100 & 100.6 & 102.6 & 100.4 & 100.9 \\
\hline
\end{tabular}

は認められなかった. $\mathrm{pH}$, ブドウ糖残存率，ア ミノ酸残存率はいずれも冷暗所保存28日後まで変 動は認められなかった。

ワンバッグ型製剤である UC-N の外包装開封後 の安定性試験結果を表11，12に示した。 UC-Nの
外観は開封直後から微黄色澄明であったが, 室温 保存, 冷暗所保存ともに変色は認められなかっ た. $\mathrm{T}_{430} \%$ は室温保存14日後, 冷暗所保存28日後 でも $98 \%$ 以上りり, 変動は認められなかった. $\mathrm{pH}$ は4.3と他の 2 製剤に比べると低めであるが， 
表 9. 隔壁開通後の安定性一室温保存（蛍光灯500lux 1日約10時間照射） アミノトリパ®2号

\begin{tabular}{|c|c|c|c|c|c|}
\hline & 開封直後 & 1日後 & 3日後 & 7日後 & 14 日後 \\
\hline 外篗 & 無色清澄 & 無色清澄 & 無色清澄 & 微黄色清澄 & 微黄色清澄 \\
\hline $\mathrm{T} 430 \%$ & 98.8 & 99.0 & 99.0 & 98.8 & 98.3 \\
\hline $\mathrm{pH}$ & 5.57 & 5.52 & 5.50 & 5.50 & 5.50 \\
\hline ブドウ糖残存率（\%) & 100 & 102.3 & 99.5 & 98.6 & 98.4 \\
\hline アミノ酸残存率（\%) & & & & & \\
\hline アスパラギン酸 & 100 & 99.1 & 99.2 & 99.2 & 100.7 \\
\hline トレオニン & 100 & 99.5 & 99.2 & 98.9 & 99.6 \\
\hline セリン & 100 & 99.3 & 99.3 & 99.2 & 100.7 \\
\hline グルタミン酸 & 100 & 99.2 & 99.6 & 99.2 & 99.9 \\
\hline プロリン & 100 & 100.6 & 100.6 & 100.4 & 100.8 \\
\hline グリシン & 100 & 99.0 & 99.0 & 98.8 & 99.5 \\
\hline アラニン & 100 & 99.0 & 99.1 & 99.2 & 99.7 \\
\hline バリン & 100 & 99.1 & 98.8 & 98.8 & 100.7 \\
\hline メチオニン & 100 & 99.5 & 99.4 & 98.2 & 99.3 \\
\hline イソロイシン & 100 & 99.2 & 99.5 & 99.0 & 100.3 \\
\hline ロイシン & 100 & 99.2 & 99.7 & 98.8 & 100.8 \\
\hline チロシン & 100 & 99.2 & 100.8 & 101.8 & 102.5 \\
\hline フェニルアラニン & 100 & 99.0 & 98.1 & 98.3 & 100.3 \\
\hline ヒスチジン & 100 & 99.9 & 100.2 & 97.8 & 99.3 \\
\hline リジン & 100 & 99.0 & 100.4 & 97.4 & 100.6 \\
\hline トリプトファン & 100 & 101.4 & 101.9 & 100.4 & 99.6 \\
\hline アルギニン & 100 & 100.3 & 101.1 & 99.0 & 102.4 \\
\hline
\end{tabular}

経時的な変動は認められなかった。ブドウ糖残存 率は室温保存14日後，冷暗所保存28日後でも 99\% 以上であった。アミノ酸残存率もすべて低下は認 められなかった。

\section{考察}

ダブルバッグ型製㓮の PN-2 および $\mathrm{AT}-2$ の 外包装開封後の安定性試験で，アミノ酸液層に着 色が認められた。着色はトリプトファンの酸化分 
表10. 隔壁開通後の安定性一冷暗所保存 アミノトリパ囚 2 号

\begin{tabular}{|c|c|c|c|c|c|}
\hline & 開封直後 & 3日後 & 7日後 & 14 日後 & 28日後 \\
\hline 外籍 & 無色清澄 & 無色清澄 & 無色清澄 & 無色清澄 & 無色清澄 \\
\hline T $430 \%$ & 98.8 & 99.1 & 99.2 & 98.4 & 99.1 \\
\hline $\mathrm{pH}$ & 5.57 & 5.52 & 5.53 & 5.53 & 5.53 \\
\hline ブドウ糖残存率（\%) & 100 & 104.8 & 102.1 & 99.1 & 101.4 \\
\hline アミノ酸残存率（\%) & & & & & \\
\hline アスパラギン酸 & 100 & 101.9 & 102.3 & 101.7 & 100.9 \\
\hline トレオニン & 100 & 101.3 & 101.7 & 100.5 & 99.8 \\
\hline セリン & 100 & 101.5 & 102.1 & 101.6 & 101.2 \\
\hline グルタミン酸 & 100 & 101.6 & 102.6 & 100.8 & 100.1 \\
\hline プロリン & 100 & 99.7 & 101.4 & 99.8 & 99.9 \\
\hline グリシン & 100 & 100.2 & 101.2 & 100.2 & 99.3 \\
\hline アラニン & 100 & 100.1 & 100.7 & 100.1 & 99.6 \\
\hline パリン & 100 & 100.7 & 101.8 & 100.8 & 100.6 \\
\hline メチオニン & 100 & 101.0 & 102.0 & 100.6 & 99.6 \\
\hline イソロイシン & 100 & 101.7 & 102.6 & 101.2 & 100.5 \\
\hline ロイシン & 100 & 101.5 & 102.3 & 100.8 & 100.3 \\
\hline チロシン & 100 & 100.8 & 102.3 & 100.4 & 100.4 \\
\hline フェニルアラニン & 100 & 100.8 & 101.4 & 99.9 & 99.8 \\
\hline ヒスチジン & 100 & 100.6 & 102.1 & 100.9 & 100.6 \\
\hline リジン & 100 & 100.5 & 100.9 & 101.5 & 100.5 \\
\hline トリプトファン & 100 & 102.9 & 103.3 & 102.9 & 99.5 \\
\hline アルギニン & 100 & 101.3 & 102.6 & 102.9 & 102.1 \\
\hline
\end{tabular}

解により黄色のキヌレニンが生成してくるために 起こるものであり ${ }^{6)}$ ，トリプトファンの分解指標 である $\mathrm{A}_{350} に も$ 経時的な上昇が認められた。しか しキヌレニンは微量でも黄色が強く, $\mathrm{A}_{350}$ : 0.875 でもキヌレニン水溶液濃度は $0.005 \mathrm{~W} / \mathrm{V} \% に$
過ぎないため7), トリプトファンの分解は問題と ならない。

ブドウ糖の加熱による分解物 5 -ヒドロキシメ チルフルフラールの指標となる $\mathrm{A}_{284}$ は, 日本薬局 方医薬品各条「ブドウ糖注射液」の純度試験で 
表11．外包装開封後の安定性一室温保存（蛍光灯500lux 1日約10時間照射） ユニカリック ${ }^{\circledR} \mathrm{N}$

\begin{tabular}{|c|c|c|c|c|c|}
\hline & & & & & $n=3$ \\
\hline & 開封直後 & 1日後 & 3日後 & 7日後 & 14日後 \\
\hline 外観 & 微黄色清澄 & 微黄色清澄 & 微黄色清澄 & 微黄色清澄 & 微黄色清澄 \\
\hline T $430 \%$ & 98.1 & 98.6 & 98.9 & 98.6 & 98.4 \\
\hline $\mathrm{pH}$ & 4.32 & 4.32 & 4.31 & 4.30 & 4.31 \\
\hline ブドウ糖残存率 (\%) & 100 & 101.8 & 99.8 & 100.2 & 99.6 \\
\hline \multicolumn{6}{|l|}{ アミノ酸残存率（\%） } \\
\hline アスパラギン酸 & 100 & 98.2 & 100.4 & 97.9 & 98.5 \\
\hline トレオニン & 100 & 98.8 & 100.5 & 98.4 & 99.1 \\
\hline セリン & 100 & 98.5 & 100.3 & 97.7 & 98.8 \\
\hline プロリン & 100 & 100.7 & 100.6 & 99.5 & 99.7 \\
\hline グリシン & 100 & 100.0 & 101.5 & 99.2 & 100.2 \\
\hline アラニン & 100 & 100.4 & 102.2 & 99.9 & 101.1 \\
\hline バリン & 100 & 99.5 & 101.2 & 99.2 & 100.0 \\
\hline メチオニン & 100 & 98.4 & 100.3 & 97.9 & 98.1 \\
\hline イソロイシン & 100 & 99.5 & 101.1 & 98.6 & 99.2 \\
\hline ロイシン & 100 & 98.3 & 100.1 & 98.1 & 98.6 \\
\hline チロシン & 100 & 97.0 & 98.7 & 95.6 & 97.2 \\
\hline フェニルアラニン & 100 & 98.4 & 100.5 & 98.4 & 99.5 \\
\hline ヒスチジン & 100 & 99.2 & 101.3 & 99.1 & 99.4 \\
\hline リジン & 100 & 98.5 & 100.0 & 97.7 & 98.2 \\
\hline トリプトファン & 100 & 100.4 & 104.3 & 100.4 & 96.8 \\
\hline アルギニン & 100 & 100.1 & 101.1 & 100.5 & 101.0 \\
\hline
\end{tabular}

0.80 以下と規定されている. 今回の試験では PN-2 および AT-2のいずれも規定数值以下であ り，経時的な変動も見られなかったことから外包 装開封によるブドゥ糖への影響はないと考えられ る.

PN-2 およびAT-2の隔壁開通後の安定性試験
ではわずかに着色が見られたものの，ブドウ糖残 存率やアミノ酸残存率の低下はほとんどみられな かったことから，臨床的には問題はないと言え る。ワンバッグ型製牏である UC-N の外包装を開 封するとダブルバッグ型製剤の隔壁を開通した場 合と同じ条件になるので，隔壁開通後の試験と同 
表12. 外包装開封後の安定性一冷暗所保存ユニカリック ${ }^{\circledR} \mathrm{N}$

\begin{tabular}{|c|c|c|c|c|c|}
\hline & & & & & $n=3$ \\
\hline & 開封亩後 & 3日後 & 7日後 & 14 日後 & 28 日後 \\
\hline 外観 & 微黄色清澄 & 微黄色清澄 & 微黄色清澄 & 微黄色清澄 & 微黄色清澄 \\
\hline T $430 \%$ & 98.1 & 98.1 & 98.5 & 98.5 & 98.2 \\
\hline $\mathrm{pH}$ & 4.32 & 4.31 & 4.34 & 4.34 & 4.33 \\
\hline ブドウ糖残存率 $(\%)$ & 100 & 104.1 & & 100.6 & 100.1 \\
\hline アミノ酸残存率（\%) & & & & & \\
\hline アスパラギン酸 & 100 & 98.3 & 97.5 & 99.4 & 100.6 \\
\hline トレオニン & 100 & 99.1 & 98.5 & 101.4 & 100.4 \\
\hline セリン & 100 & 99.0 & 98.0 & 101.0 & 100.4 \\
\hline プロリン & 100 & 98.7 & 98.0 & 100.9 & 100.2 \\
\hline グリシン & 100 & 98.6 & 98.5 & 101.8 & 99.3 \\
\hline アラニン & 100 & 98.4 & 98.5 & 102.2 & 99.6 \\
\hline パリン & 100 & 100.1 & 98.8 & 101.9 & 101.9 \\
\hline メチオニン & 100 & 99.3 & 98.3 & 101.8 & 100.0 \\
\hline イソロイシン & 100 & 99.5 & 99.0 & 101.8 & 100.4 \\
\hline ロイシン & 100 & 98.7 & 97.8 & 99.9 & 98.4 \\
\hline チロシン & 100 & 99.3 & 97.9 & 102.7 & 99.9 \\
\hline フェニルアラニン & 100 & 99.5 & 98.4 & 101.3 & 99.8 \\
\hline ヒスチジン & 100 & 100.3 & 99.1 & 101.4 & 99.9 \\
\hline リジン & 100 & 97.8 & 98.1 & 101.4 & 99.2 \\
\hline トリプトファン & 100 & 100.9 & 101.3 & 103.9 & 102.0 \\
\hline アルギニン & 100 & 100.5 & 100.6 & 102.0 & 101.7 \\
\hline
\end{tabular}

様の試験項目を設定した。UC-N は試験前から微 黄色清澄の外観であったため, 外観上の変化は確 認できなかったが, ブドウ糖残存率，アミノ酸残 存率ともに低下はなかったことから，やはり臨床 上は問題とならないと思われる.

以上のことから, 亜硫酸水素ナトリウム添加量 を減らした改良型ピーエヌッイン®の外包装開封
後打よび隔壁開通後の安定性は従来と変わらず, 他の TPN キット製剤のアミノトリパ®やユニカ リックにについても安定性はほぼ同等であること がわかった，外包装開封後あるいは隔壁開通後の TPN キット製剤はただちに使用するべきではあ るが，やむを得ない場合は室温保存で14日以内， 冷暗所保存で28日以内に使用すれば品質に影響は 
ないと考えられる.

\section{引用文献}

1) 浜田康次, 井口理恵, 吉原貴子, JPEN, 18, 557-565 (1996).

2) 山岡桂子, 中島康雄, JJSHP, 31, 717-724 (1995).

3) 第13改正日本薬局方解説書, 廣川書店, 東京,
C 613-619, (1996).

4) J.L.Smith, J.E.Canham and P.A.Wells, JPEN., 12, 394-402 (1988).

5）日本へキストマリオンルセル社，ピーエヌッイ ン®添付文書改訂のお知らせ (1996).

6) 石黒伊三雄, 長村洋一, 生化学, 44, 22-31 (1972).

7）日本へキストマリオンルセル社内資料 